\title{
Measuring changes in preferences and perception due to the entry of a new brand with choice data
}

\author{
Lutz Hildebrandt* \\ Lea Kalweit*
}

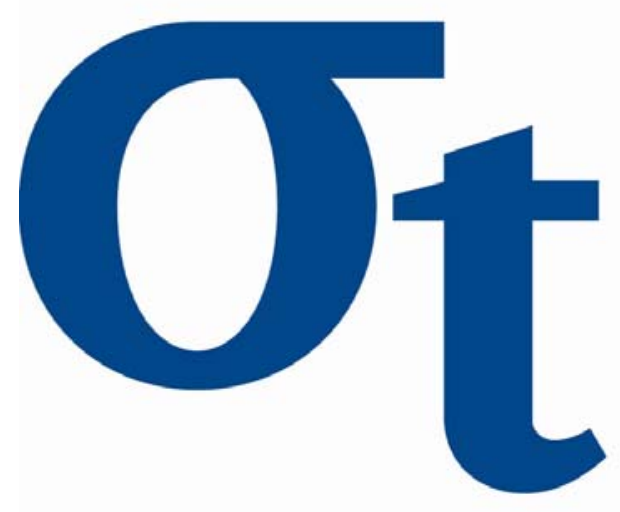

9

$\forall$

6

* Humboldt-Universität zu Berlin, Germany

This research was supported by the Deutsche Forschungsgemeinschaft through the SFB 649 "Economic Risk". 


\title{
Measuring changes in preferences and perception due to the entry of a new brand with choice data ${ }^{1}$
}

\author{
Lutz Hildebrandt, Lea Kalweit ${ }^{2}$ \\ Institute of Marketing \\ School of Business and Economics \\ Humboldt University Berlin \\ hildebr@wiwi.hu-berlin.de
}

\begin{abstract}
:
Context effects can have a major influence on brand choice behavior after the introduction of a new product. Based on behavioral literature, several hypotheses about the effects of a new brand on perception, preferences and choice behavior can be derived, but studies with real choice data are still lacking. We employ an internal market structure analysis to measure context effects caused by a new product in scanner panel data, and to discriminate between alternative theoretical explanations. An empirical investigation reveals strong support for categorization effects and changes in perception, which affect customers in two out of five segments.
\end{abstract}

\section{Keywords:}

context effects, categorization, brand choice models, new brand introduction

JEL-Codes:

M31, C23, C51

\footnotetext{
${ }^{1}$ Financial support by the Deutsche Forschungsgemeinschaft (DFG) through the SFB 649 „Economic Risk“ is gratefully acknowledged.

${ }^{2}$ Lea Kalweit is currently working at the global market research department of the Bayer Schering Pharma AG.
} 


\section{Introduction}

Besides their theoretical value for understanding individual decision-making and choice behavior, context effects have important practical relevance for both predicting consumer brand choice, and designing and positioning new products. In a brand choice situation, context effects refer to the changes in the choice process and its outcome as a function of the particular brands that are included in the choice set (Chakravarti \& Lynch, 1983).

Van Heerde et al. (2004) observe increasing price and cross-price elasticities due to the appearance of an innovative new brand. They explain their findings by perceptual changes driven by range-effects or categorization but offer no proof for this conjecture. Perceptual changes are one of several context effects that have been shown to be related to the introduction of new alternatives. Starting with work of Huber et al. (1982), context effects have been extensively studied in experimental research. Recent research seeks explanations that can be integrated into the value maximization framework. On the one hand, the literature on context effects provides a broad theoretical foundation for market entry effects, which allows us to derive specific hypotheses about how the entry of a new brand affects choice, given the entry position and assumptions with regard to the mechanism that operates on individual decision-making. On the other hand, empirical studies using real choice data to validate experimental findings are still lacking. Until now, not much attention was paid to these effects in studies of changes in market structure due to new brand entries. Rather, they were disregarded in individual brand choice models, in dynamic models of market structure and in most positioning models, despite the fact that they may play a role in explaining observable changes in a market after a new product entry.

We argue that context effects can be observed and measured in real choice behavior. Our study focuses on measuring context effects and revealing their mechanisms in scanner panel data. We propose a framework in which alternative hypotheses about entry effects on individual brand choice behavior can be statistically tested. This framework allows us to discriminate between alternative mechanisms behind context effects, for example changes in perception and preferences. Context effects are a major source of changes in market structure, even if the new product is not innovative, i.e., very similar to existing brands. While other studies majorly focus on really innovative and distinctive new products, this study 
investigates the entry of a new brand with only minor changes in the product concept in a fast moving consumer goods category.

Our study demonstrates the external validity of context effects in real choice behavior and overcomes several limitations of experimental research on context effects. A severe shortcoming of all previous experimental studies is their disregard of heterogeneity, which might exist for underlying preferences, as well as for the individual response to an entry. Previous studies have generally been restricted to only two existing brands and a third new brand, and have been designed in a between-subjects mode, which does not allow for determination of what happens to the choice process of a given individual (Steward, 1989). Thus, it has been impossible for the true operating mechanism to be identified. Empirical studies with scanner panel data using the information of more complex market situations, such as ours, have the potential to clarify this issue.

\section{Context effects and new product entry}

Extensive experimental evidence from context effect research indicates that even a similar new alternative can induce significant changes in brand choice behavior. The availability of a new brand alters the decision context of a consumer and thus influences his decision. Changes in the set of alternatives can induce shifts in choice-probabilities, like the attraction effect (Huber et al., 1982; Huber \& Puto, 1983), the similarity effect (Tversky, 1972), and the compromise effect (Simonson, 1989). Numerous theoretical explanations (e.g., Simonson \& Tversky, 1992) and different conceptual modeling approaches incorporating context effects into the value maximization framework have been proposed. Recent studies that consider the mechanisms driving context effects reveal an interface for implementing an empirical analysis based on individual level choice data.

The contingent weight model by Tversky and Simonson (1993) and the weight-change model by Wedell (1991) attribute shifts in preferences to changes in attribute important weights. Possible reasons for changes in weights are range-frequency-effects, shifts in attention or salience of attributes (e.g. Huber et al. 1982; Wedell, 1991) or a dynamic choice reconstruction to yield subjective dominance between options (Ariely \& Wallsten, 1995). Several researchers identified preference weight changes as the cause for context effects (e.g. Ariely \& Wallsten, 1995; Huber et al., 1982; Pan \& Lehmann, 1993; Simonson \& Tversky, 
1992; Wernerfelt, 1995). In contrast, recent studies suggest that changes in the cognitive representation of stimuli are the reason for context effects (Dhar \& Glazer, 1996; Wedell, 1991; Wedell \& Pettibone, 1996). These studies attribute preference shifts to changes in the perception of similarity between choice options represented on underlying perceptual dimensions. They demonstrate the interdependence between violations of preference invariance and violations of perceptual invariance. Due to asymmetric shifts in the perceptual space, certain brands become more desirable. Perceptual distortions can be induced by rangefrequency effects (Parducci, 1974), categorization (Pan \& Lehmann, 1993), density effects (Krumhansl 1978) and assimilation or contrast effects (Sherif, 1963; Sherif \& Hovland, 1961). As opposed to the weight change account, which does not postulate a precise causality between a specific entry position and the direction of change, the value-shift account based on the aforementioned perceptual theories allows precise predictions of perceptual distortions and their implications for preferences and choice. Attempts to discriminate between both mechanisms with experiments yield controversial findings (e.g. Wedell \& Pettibone, 1996; Dhar \& Glazer, 1996).

\section{Method}

We apply a brand choice modeling approach to market structure analysis (Chintagunta, 1994, 1999) in order to measure structural changes in preferences with scanner panel data. Our model builds on the mixed logit model (Kamakura \& Russell, 1989) and the choice-map approach of Elrod (1988). With test market scanner panel data, and by means of parameter restrictions, a combined pre- and post-entry model can be applied to test hypotheses about contextual changes in preference structures. Two goals are central to this approach: to model preference structures with individual-level scanner panel data taking into account heterogeneity, and to extract a perceptual space which represents both the perceived substitutability and the preferences. A multi-dimensional linear preference structure is recovered from observed brand switching behavior. In this framework, alternative hypotheses regarding changes in preference structure and perceived product positions can be statistically tested using model restrictions.

Following Chintagunta (1994), the preference structure is extracted from the brand intercept $\beta_{0 i j}$ in the random utility of the multinomial logit model. The brand intercept $\beta_{0 i j}$ in household $i$ 's utility $U_{i j}=\beta_{0 i}+\beta_{i}{ }^{\prime} X_{i j t}+\varepsilon_{i j}$ for brand $j$ on occasion $t$ can be interpreted as the 
intrinsic preference an individual assigns to an alternative (Kamakura \& Russell, 1992). It is assumed to be relatively stable over time and purchase occasions. Changes in choice probabilities are accounted for by response on situational factors $X_{i j t}$, for example marketing mix. To account for unobservable heterogeneity in preferences and response, $\theta_{\mathrm{i}}=\left\{\beta_{0 i}, \beta_{i}\right\}$ is assumed to be drawn from a discrete distribution with a finite number of supports $S$ and associated probabilities $\rho\left(\theta_{\mathrm{s}}\right)$. The brand preferences $\beta_{0 i}$ are decomposed into the positions of all alternatives in a $m$-dimensional perceptual space of product attributes $A$ and householdspecific important weights $W_{i}$ by $\beta_{0 i}=A W_{i}$. The weights are allowed to differ across segments, whereas product positions are assumed to be common for all individuals. Assuming a type I extreme value distribution for the random term $\varepsilon_{i j}$ the conditional choice probability for consumer $i$ in segment $s$ of choosing brand $j$ is

$$
P_{i j t}=\exp \left(a_{j} w_{s}+\beta_{s}{ }^{\prime} X_{i j t}\right) / \sum_{l=1}^{J} \exp \left(a_{l} w_{s}+\beta_{s}{ }^{\prime} X_{i l t}\right)
$$

The unconditional probability is a weighted average of the logit evaluated at different parameter values (Kamakura \& Russell, 1989). The introduction of a new brand can alter the preference structure $\beta_{0 i}=A W_{i}$. and thus choice probabilities. Assuming that individual choices are independent across all purchase incidents, and that preferences are stable before and after the brand entry, two periods $\tau=1,2$ with different choice sets ( $J_{\tau=1}$ is a subset of $J_{\tau=2}$ ) can be identified. The likelihood function of household $i$ can be specified as

$$
l\left(y_{i}\right)=\sum_{s=1}^{S}\left[\prod_{t=1}^{T_{\tau=1}}\left\{\prod_{j=1}^{J_{\tau=1}} P_{\tau=1, i j t} \delta_{j i t}\right\} \times \prod_{t=1}^{T_{\tau=2}}\left\{\prod_{j=1}^{J_{\tau=2}} P_{\tau=2, i j t} \delta_{j i t}\right\}\right] \rho\left(\theta_{s}\right) .
$$

It is assumed that segment sizes $\rho\left(\theta_{\mathrm{s}}\right)$ do not change. Parameters are simultaneously estimated with standard maximum-likelihood methods across both periods. Starting with the most restrictive specification, brand preferences do not change, brand entry effects can be modeled by reducing parameter restrictions on the preference structure for both periods. Model restrictions can apply either to segment specific preference weights or to brand positions in the perceptual space. Effects are uniquely represented by their specific combination of entryposition, change of preferences or positions and change of choice shares.

The model accounts for the non-stationary nature of marketing-mix variables. The finite mixture specification of heterogeneity allows us to examine context effects on a segment 
basis and overcome the restrictive IIA assumption, at least at the aggregate level (Kamakura \& Russell, 1989). Given specific preferences, not every customer has to exhibit context effects. The finite mixture logit model with market structure allows the new brand to draw market shares non-proportionally from the existing brands (McFadden \& Train, 2000). The interaction of product attributes with random segment preference weights induces correlations amongst the utilities of alternatives, which explicitly reflect substitution patterns and their proximity in the product space (Brownstone \& Train, 1999). Although some restrictions must be imposed to ensure identification of the linear preference model, and to fix the invariance in the scale of weights and perceptual dimensions, context effects based on value-shifts of weights changes can be represented.

Two recent modeling approaches to incorporate context effects into the random utility framework are given by Kivetz et al. (2004) and Haaijer et al. (1998). Kivetz et al. (2004) primarily correct for compromise effects in the estimation of part-worth in conjoint experiments by choice set dependent transformations in the utility function. In contrast to their approach, our method is more flexible since it is not restricted to a specific type of context effect. Haaijer et al. (1998) account for random variation in weights or part worth in a choice-based conjoint analysis by means of a random coefficient specification. This allows them to assess the amount of context-dependent variation in utilities, while our approach explicitly identifies distinct effects and their direction.

\section{Empirical study}

The analysis is based on 104 weeks of US IRI scanner panel data from the ice cream product category. Context effects in this category have already been subject to an experimental investigation by Simonson (1990). We selected only individual panelists to ensure closeness to the psychological phenomena we intend to measure. Including only the most important brands, this gave rise to a sample size of $\mathrm{N}=2337$ for the two-period dataset. The market is divided in a high price, high quality premium segment (2, 6, 9 and entry) and a non-premium segment (3, 4, 5, 7 and 8) of brands. Inspection of market shares in the pre- and post entry period (39 and 65 weeks) indicates an increase in share for brand 2 and 6 while brand 9 loses after the introduction of the new brand 1 , which is a new product line of low-fat frozen yogurt ice by Ben \& Jerry’s. Average regular prices remain quite unchanged (Table 1). 
Table 1

Choice Shares and Marketing Mix in Pre- and Post-entry Period

\begin{tabular}{|c|c|c|c|c|c|c|c|c|c|c|c|}
\hline \multirow[b]{3}{*}{ Brand } & \multirow{2}{*}{\multicolumn{2}{|c|}{ Choice Share }} & \multirow[b]{3}{*}{$\Delta$} & \multirow{2}{*}{\multicolumn{2}{|c|}{ Mean Price }} & \multicolumn{2}{|c|}{ Feature } & \multicolumn{2}{|c|}{ Display } & \multicolumn{2}{|c|}{ Price Cut } \\
\hline & & & & & & (Frequ & iency) & (Frequ & iency) & (Freql & iency) \\
\hline & $\tau=1$ & $\tau=2$ & & $\tau=1$ & $\tau=2$ & $\tau=1$ & $\tau=2$ & $\tau=1$ & $\tau=2$ & $\tau=1$ & $\tau=2$ \\
\hline 1 BEN \& JERRYS BFY & & 2.27 & +2.27 & . & 2.74 & $\cdot$ & 0.04 & . & 0.03 & . & 0.11 \\
\hline 2 BEN \& JERRYS & 2.86 & 4.34 & +1.48 & 2.73 & 2.73 & 0.03 & 0.07 & 0.00 & 0.03 & 0.14 & 0.16 \\
\hline 3 BREYERS & 14.66 & 16.62 & +1.96 & 0.89 & 0.97 & 0.25 & 0.19 & 0.01 & 0.03 & 0.24 & 0.33 \\
\hline 4 DEANS FOODS & 10.37 & 7.88 & -2.49 & 0.87 & 0.90 & 0.22 & 0.18 & 0.02 & 0.04 & 0.16 & 0.22 \\
\hline 5 DREYERS EDYS & 7.99 & 11.28 & +3.30 & 1.18 & 1.17 & 0.15 & 0.15 & 0.04 & 0.10 & 0.22 & 0.26 \\
\hline 6 HAAGEN DAZS & 21.45 & 22.96 & +1.51 & 2.51 & 2.59 & 0.25 & 0.24 & 0.03 & 0.08 & 0.29 & 0.30 \\
\hline 7 KEMPS & 10.61 & 14.82 & +4.21 & 0.93 & 0.96 & 0.17 & 0.19 & 0.05 & 0.10 & 0.25 & 0.26 \\
\hline 8 SEALTEST & 20.38 & 14.82 & -5.56 & 0.81 & 0.76 & 0.21 & 0.18 & 0.01 & 0.03 & 0.26 & 0.26 \\
\hline 9 SIMPLE PLEASURES & 11.68 & 5.01 & -6.67 & 2.45 & 2.60 & 0.08 & 0.05 & 0.02 & 0.00 & 0.20 & 0.16 \\
\hline
\end{tabular}

The number of latent segments was determined using the static two-dimensional model (Chintagunta, 1994) for brands 2-9 and the entire time period. Based on information criteria, the number of segments selected for the following analysis is 5 (Table 2).

Table 2

Model Fit and Number of Segments $\left(N^{*}=2378\right)$ for Static Model

\begin{tabular}{cccccc} 
Segments & $\ell$ & BIC & AIC & AIC3 & CAIC \\
\hline 3 & -2848.89 & 2969.39 & 5759.79 & 5790.79 & 5969.78 \\
4 & -2657.05 & 2804.75 & 5390.09 & 5428.09 & 5647.51 \\
5 & -2447.21 & 2622.12 & 4984.41 & 5029.41 & 5289.24 \\
6 & -2467.02 & 2669.14 & 5038.03 & 5090.03 & 5390.28 \\
\hline
\end{tabular}

* sample size with 8 brands in both periods

The predicted market shares by the static solution (Table 3) point out that segments 3 and 5 switch predominantly within the premium brands. They are expected to be the major adopters of the new brand and thus potentially influenced by context effects, whereas segments 1,2 and 4 , due to their very distinct preferences, do not choose among the premium brands. The 
entry of brand 1 is expected to be located close to the premium brands. It is also not expected to perceive an extreme or significant range extension effect.

Table 3

Predicted Choice Shares Based on Static Solution for the Entire Period and Original Observations

\begin{tabular}{crrrrrrrr}
\hline Brand & 2 & 3 & 4 & 5 & 6 & 7 & 8 & 9 \\
\hline Seg. 1 & 0.91 & 66.54 & 2.79 & 1.89 & 13.26 & 7.30 & 6.96 & 0.36 \\
Seg. 2 & 1.02 & 11.40 & 10.38 & 11.85 & 3.26 & 40.12 & 19.14 & 2.83 \\
Seg. 3 & 26.09 & 1.83 & 4.35 & 9.99 & 9.10 & 5.92 & 5.12 & 37.60 \\
Seg. 4 & 0.90 & 6.49 & 16.15 & 14.72 & 11.47 & 0.04 & 49.80 & 0.43 \\
Seg. 5 & 12.42 & 4.99 & 0.57 & 1.46 & 73.79 & 2.61 & 0.54 & 3.62 \\
\hline Predicted & 8.31 & 12.78 & 7.58 & 8.81 & 22.96 & 12.57 & 18.13 & 8.85 \\
\hline Actual & 3.91 & 15.85 & 9.00 & 10.26 & 23.25 & 13.25 & 16.69 & 7.78 \\
\hline
\end{tabular}

Table 4 gives a general description of the hypothesis examined in the data. Models $\mathrm{H}_{2}, \mathrm{H}_{3}, \mathrm{H}_{4}$ test for the weight-change hypothesis. Models $\mathrm{H}_{5}, \mathrm{H}_{6}, \mathrm{H}_{7}$ investigate perceptual distortions that might have occurred.

Table 4

Hypothesis and Model Specification

\begin{tabular}{|c|c|c|c|}
\hline \multirow[t]{2}{*}{ Hypothesis } & \multirow[t]{2}{*}{ Description } & \multicolumn{2}{|c|}{ Specification } \\
\hline & & $A$ & $w$ \\
\hline $\mathbf{H}_{\mathbf{0}}$ & null-model, all preference parameters estimated & $A_{\tau=1} \neq A_{\tau=2}$ & $W_{\tau=1} \neq W_{\tau=2}$ \\
\hline $\mathbf{H}_{1}$ & no effect, all parameters fixed across $\tau=1,2$ & $A_{\tau=1}=A_{\tau=2}$ & $W_{\tau=1}=W_{\tau=2}$ \\
\hline $\mathbf{H}_{2}$ & weight-change for segment $s=3$ & $A_{\tau=1}=A_{\tau=2}$ & \\
\hline $\mathbf{H}_{3}$ & weight-change for segment $s=5$ & $A_{\tau=1}=A_{\tau=2}$ & for $s \neq l$ and \\
\hline $\mathbf{H}_{4}$ & weight-change for segment $s=3,5$ & $A_{\tau=1}=A_{\tau=2}$ & $w_{l, \tau=1} \neq w_{l, \tau=2}$ \\
\hline $\mathbf{H}_{5}$ & value-shift for all brands & $A_{\tau=1} \neq A_{\tau=2}$ & $W_{\tau=1}=W_{\tau=2}$ \\
\hline $\mathbf{H}_{6}$ & value-shift for sub-group $T$ of brands ( $k=2,9,6)$ & $a_{k, \tau=1}=a_{k, \tau=2}$ & $W_{\tau=1}=W_{\tau=2}$ \\
\hline $\mathbf{H}_{7}$ & value-shift for sub-group $T$ of brands ( $k=2,9$ ) & for $k \notin T$ & \\
\hline
\end{tabular}




\section{Results}

Table 5 documents fit statistics for all estimated models. BIC and CAIC account for sample size and impose a higher penalty on the number of parameters than AIC and AIC3. Corresponding to BIC and CAIC the value-shift model with regard to the position of the premium brands 2, 6 and 9 best describes the observed changes in brand choice behavior. Model 2, which is equivalent to the static model except that the position of the entry is estimated, is not supported by any criteria. The assumption that the entry of brand 1 does not affect the choice probabilities of the existing brands clearly has to be rejected. The competing weight-change hypothesis is also not supported by the data.

Table 5

Model Selection (minimum value in boldface)

\begin{tabular}{lcccccc}
\hline Model & $\ell$ & BIC & AIC & AIC3 & CAIC & \#Parameter \\
\hline $\mathbf{H}_{\mathbf{0}}$ & -2397.024 & 2660.749 & $\mathbf{4 9 3 0 . 0 4 7}$ & $\mathbf{4 9 9 8 . 0 4 7}$ & 5389.498 & 68 \\
\hline $\mathbf{H}_{\mathbf{1}}$ & -2472.864 & 2655.145 & 5039.728 & 5086.728 & 5357.289 & 47 \\
$\mathbf{H}_{\mathbf{2}}$ & -2464.963 & 2655.000 & 5027.926 & 5076.926 & 5359.001 & 49 \\
$\mathbf{H}_{\mathbf{3}}$ & -2468.583 & 2658.620 & 5035.165 & 5084.165 & 5366.240 & 49 \\
$\mathbf{H}_{\mathbf{4}}$ & -2461.624 & 2659.418 & 5025.248 & 5076.248 & 5369.836 & 51 \\
$\mathbf{H}_{\mathbf{5}}$ & -2420.669 & 2653.368 & 4961.338 & 5021.338 & 5366.735 & 60 \\
$\mathbf{H}_{\mathbf{6}}$ & -2441.067 & $\mathbf{2 6 4 6 . 6 1 7}$ & 4988.133 & 5041.133 & $\mathbf{5 3 4 6 . 2 3 4}$ & 53 \\
$\mathbf{H}_{\mathbf{7}}$ & -2457.562 & 2655.356 & 5017.125 & 5068.125 & 5361.712 & 51 \\
\hline
\end{tabular}

Model 7 is consistent with the value-shift accounts of Dhar \& Glazer (1996), Wedell (1991) und Wedell \& Pettibone (1996). A change in preferences originates from the categorization of brands due to the new brand becoming available (Pan \& Lehmann, 1993). The product space reveals that the distances between brands 2, 6 and 9 have decreased (see following Figure 1).

Categorization corresponds to diminishing differentiation in the premium segment of the market (note that implications for market structure only apply for the sample of individual panelists). Brand 9 loses its outstanding position, which results in smaller choice probabilities in both segments 3 and 5 (Table 6). 
Figure 1 Two-dimensional Product Space for Pre- and Post-entry Period for Model 7

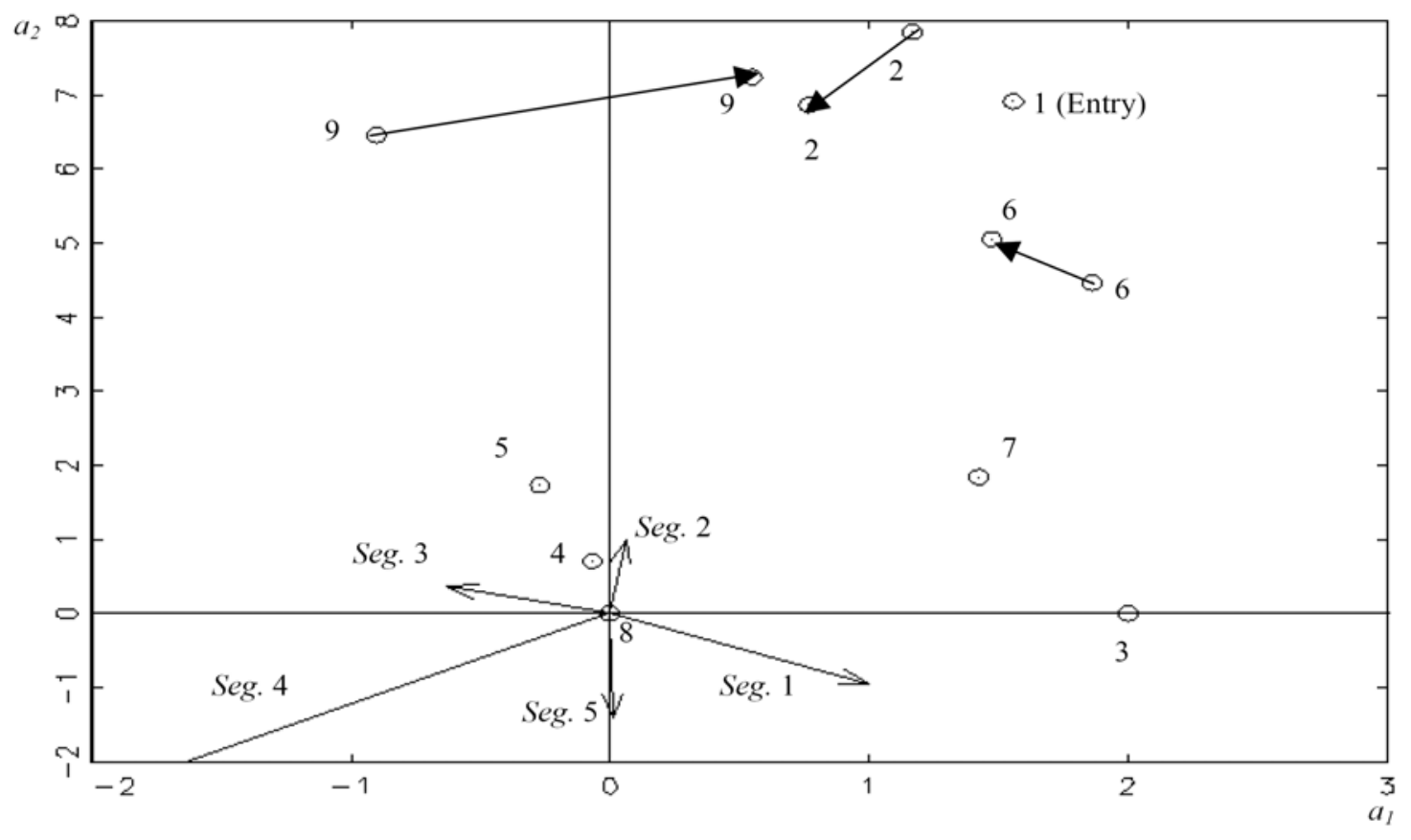

Table 6

Predicted Choice Shares in Pre- and Post-entry Period Based on Model 7 and Original Observations

\begin{tabular}{|c|c|c|c|c|c|c|c|c|c|}
\hline Brand & 2 & 3 & 4 & 5 & 6 & 7 & 8 & 9 & 1 \\
\hline Seg. 1 & 0.98 & 63.60 & 2.92 & 2.15 & 16.13 & 6.29 & 7.66 & 0.26 & \\
\hline Seg. 2 & 2.39 & 12.38 & 12.31 & 9.72 & 0.15 & 41.97 & 17.18 & 3.89 & \\
\hline Seg. 3 & 22.03 & 1.36 & 3.81 & 8.32 & 4.66 & 3.25 & 4.69 & 51.89 & \\
\hline Seg. 4 & 0.01 & 3.59 & 12.72 & 13.17 & 9.12 & 0.02 & 58.27 & 3.10 & \\
\hline Seg. 5 & 5.05 & 2.21 & 0.77 & 1.44 & 82.33 & 0.27 & 1.24 & 6.68 & \\
\hline Predicted & 6.12 & 12.82 & 7.38 & 7.76 & 20.19 & 12.09 & 20.17 & 13.47 & \\
\hline Actual & 2.86 & 14.66 & 10.37 & 7.99 & 21.45 & 10.61 & 20.38 & 11.68 & \\
\hline Seg. 1 & 0.93 & 67.53 & 3.01 & 2.01 & 11.92 & 6.28 & 6.50 & 0.33 & 1.49 \\
\hline Seg. 2 & 0.39 & 9.60 & 10.02 & 12.85 & 4.90 & 40.18 & 21.04 & 0.80 & 0.22 \\
\hline Seg. 3 & 22.24 & 1.65 & 4.78 & 10.57 & 13.52 & 4.01 & 5.66 & 26.97 & 10.59 \\
\hline Seg. 4 & 0.35 & 7.84 & 18.84 & 15.90 & 12.57 & 0.03 & 44.40 & 0.04 & 0.04 \\
\hline Seg. 5 & 14.36 & 3.27 & 1.14 & 1.89 & 63.98 & 0.38 & 0.96 & 3.85 & 10.16 \\
\hline Predicted & 7.42 & 13.87 & 8.51 & 9.71 & 20.11 & 11.82 & 17.88 & 6.42 & 4.25 \\
\hline Actual & 4.34 & 16.62 & 7.88 & 11.28 & 22.96 & 14.82 & 14.82 & 5.01 & 2.27 \\
\hline
\end{tabular}


In contrast to brand 9, brand 2 benefits from categorization. It becomes more attractive to segment 5 and thus increases its market share. Parameter estimates for model 7 and the static model are reported in the Appendix.

\section{Summary}

The study demonstrates the application of the proposed method to test for alternative entry effects in real choice behavior. As opposed to other recent empirical modeling approaches, it allows for discrimination between alternative mechanisms considered by context effect research. The method offers several advantages compared to an experimental approach to investigate entry effects. It utilizes real world choice data to infer preferences and examines effects on the within-subject base. It avoids measuring response language effects because it is based on real choice data (Lynch et al.,1991). By accounting for heterogeneity, not all subjects must exhibit preference or perceptual effects. Insight can be gained into consumer behavior in a realistic market setting with a variety of brands appealing to different segments.

However, it is the very nature of scanner data that gives rise to the main limitations of this approach. Influences beyond the marketing variables considered in the model (price, price cut, feature and display) might also have caused the observed shifts in choice shares, for example advertising campaigns or other changes in consumer behavior. The probability to get significant and stable results on the effects of these variables grows with an increasing time horizon in the data. Limitations also result from the assumption of a linear utility function. The translation of typical entry positions studied in experiments is a nontrivial task. Whereas other studies define alternatives by physical attributes, we extract a perceptual space. 


\section{References:}

Ariely, D., Wallsten, T. S. (1995). Seeking subjective dominance in multidimensional space: an explanation of the asymmetric dominance effect. Organizational Behavior and Human Decision Processes, 63 (3), 223-232.

Brownstone, D., Train, K. (1999). Forecasting new product penetration with flexible substitution patterns. Journal of Econometrics, 89, 109-129.

Chakravarti, D., Lynch, J. G. (1983) A framework for exploring context effects on consumer judgement and choice. Advances in Consumer Research, 10, 289-297.

Chintagunta, P. K. (1994). Heterogeneous logit model implications for brand positioning. Journal of Marketing Research, 31(2), 304-311.

Chintagunta, P. K. (1999). Measuring the effects of new brand introduction on inter-brand strategic interaction. European Journal of Operations Research, 118(2), 315-331.

Dhar, R., Glazer, R. (1996). Similarity in context: cognitive representation and the violation of preference invariance in consumer choice. Organizational Behavior and Human Decision Processes, 67(3), 326-344.

Haaijer, R., Wedel, M., Vriens, M., Wansbeek, T. (1998). Utility covariances and context effects in conjoint MNP models. Marketing Science, 17(3), 236-252.

Huber, J., Payne, J. W., Puto, C. (1982). Adding asymmetrically dominated alternatives: violations of regularity and the similarity hypothesis. Journal of Consumer Research, 9(1), 90-98.

Huber, J., Puto, C. (1983). Market Boundaries and Product Choice: Illustrating attraction and substitution effects. Journal of Consumer Research, 10(1), 31-44.

Kamakura, W., Russell, G. J. (1989). A probabilistic choice model for market segmentation and elasticity structure. Journal of Marketing Research, 26(4), 379-390.

Kamakura, W., Russell, G. J. (1992). Measuring brand value with scanner data. International Journal of Research in Marketing, 10(1), 9-22.

Kivetz, R., Netzer, O., Srinivasan, V. (2004). Alternative models for capturing the compromise effect. Journal of Marketing Research, 41(3), 237-257.

Krumhansl, C. L. (1978). Concerning the applicability of geometric models to similarity data: the interrelationship between similarity and spatial density. Psychological Review, 85, 450-463.

Lynch, J. G., Chakravarti, D., Mitra, A. (1991). Contrast effects in consumer judgments: changes in mental representations or in the anchoring of rating scales. Journal of Consumer Research, 18(3), 284-297.

McFadden, D., Train, K. (2000). Mixed MNL models for discrete response. Journal of Applied Econometrics, 15, 447-470.

Pan, Y., Lehman, D. R. (1993). The influence of new brand entry on subjective brand judgements. Journal of Consumer Research, 20(1), 76-86.

Parducci, A. (1974). Contextual effects: a range-frequency analysis. in: Carterette, L., Friedman, M. P. (eds.), Handbook of Perception, Vol. II, New York: Academic Press. 
Sherif, C. W. (1963). Social categorization as a function of latitude of acceptance and series range. Journal of Abnormal and Social Psychology, 67(2), 148-156.

Sherif, C. W., Hovland, C. I. (1961). Social judgment. New Haven: Yale University Press.

Simonson, I. (1989). Choice based on reasons: the case of attraction and compromise effect. Journal of Consumer Research, 16(2), 158-174.

Simonson, I. (1990). The effect of buying decisions on consumers' assessment of their tastes. Marketing Letters, 2(1), 5-14.

Simonson I., Twersky, A. (1992). Choice in context: tradeoff contrast and extremeness aversion. Journal of Marketing Research, 29(3), 281-295.

Stewart, D. W. (1989). On the meaningfulness of sensory attributes: further evidence on the attraction effect. Advances in Consumer Research, 18, 197-202.

Tversky, A. (1972). Elimination by aspects. Psychological Review, 79(4), 281-299.

Tversky, A., Simonson, I. (1993). Context-dependent preferences. Management Science, 39(10), 1179-1189.

Van Heerde, H. J., Mela, C. F., Manchanda, P. (2004). The dynamic effect of innovation on market structure. Journal of Marketing Research, 41(2), 166-183.

Wedell, D. H., (1991). Distinguishing among models of contextually induced preference reversals. Journal of Experimental Psychology: Learning, Memory and Cognition, 17, 767-778.

Wedell, D. H., Pettibone, J.C. (1996). Using judgements to understand decoy effects in choice. Organizational Behavior and Human Decision Processes, 67 (3), 326-344. 


\section{Appendix:}

Table A.1

Parameter Estimates - Preference Structure (standard errors in parentheses)

\begin{tabular}{|c|c|c|c|c|c|c|c|c|}
\hline & \multicolumn{4}{|c|}{ Static Model } & \multicolumn{4}{|c|}{ Model 7} \\
\hline & pre- $\epsilon$ & entry & & try & pre- & entry & post & -entry \\
\hline Weights & $w_{1}$ & $w_{2}$ & $w_{1}$ & $w_{2}$ & $w_{1}$ & $w_{2}$ & $w_{1}$ & $w_{2}$ \\
\hline Seg. 1 & $1^{*}$ & $\begin{array}{c}-0.923 \\
(0.041)\end{array}$ & - & - & $1^{*}$ & $\begin{array}{l}-0.952 \\
(0.048)\end{array}$ & - & - \\
\hline Seg. 2 & $\begin{array}{c}0.091 \\
(0.219)\end{array}$ & $1^{*}$ & - & - & $\begin{array}{c}0.062 \\
(0.368)\end{array}$ & $1^{*}$ & - & - \\
\hline Seg. 3 & $\begin{array}{c}-0.440 \\
(0.252)\end{array}$ & $\begin{array}{c}0.628 \\
(0.088)\end{array}$ & - & - & $\begin{array}{c}-0.629 \\
(0.245)\end{array}$ & $\begin{array}{c}0.368 \\
(0.075)\end{array}$ & - & \\
\hline Seg. 4 & $\begin{array}{c}-2.066 \\
(0.121)\end{array}$ & $\begin{array}{l}-3.203 \\
(0.237)\end{array}$ & - & - & $\begin{array}{c}-2.265 \\
(0.072)\end{array}$ & $\begin{array}{l}-3.549 \\
(0.052)\end{array}$ & - & - \\
\hline Seg. 5 & $\begin{array}{c}0.952 \\
(0.296)\end{array}$ & $\begin{array}{l}-0.759 \\
(0.108)\end{array}$ & - & - & $\begin{array}{c}0.013 \\
(0.411)\end{array}$ & $\begin{array}{c}-1.409 \\
(0.132)\end{array}$ & - & - \\
\hline Positions & $a_{1}$ & $a_{2}$ & $a_{1}$ & $a_{2}$ & $a_{1}$ & $a_{2}$ & $a_{1}$ & $a_{2}$ \\
\hline Brand 2 & $\begin{array}{c}0.742 \\
(0.362)\end{array}$ & $\begin{array}{c}6.931 \\
(0.356)\end{array}$ & - & - & $\begin{array}{c}1.166 \\
(0.128)\end{array}$ & $\begin{array}{c}7.852 \\
(0.277)\end{array}$ & $\begin{array}{c}0.769 \\
(0.386)\end{array}$ & $\begin{array}{c}6.866 \\
(0.228)\end{array}$ \\
\hline Brand 3 & $\begin{array}{c}2.078 \\
(0.097)\end{array}$ & $0^{*}$ & - & - & $\begin{array}{c}2.000 \\
(0.147)\end{array}$ & $0^{*}$ & - & - \\
\hline Brand 4 & $\begin{array}{c}-0.061 \\
(0.171)\end{array}$ & $\begin{array}{c}0.713 \\
(0.175)\end{array}$ & - & - & $\begin{array}{c}-0.069 \\
(0.121)\end{array}$ & $\begin{array}{c}0.704 \\
(0.151)\end{array}$ & - & - \\
\hline Brand 5 & $\begin{array}{c}-0.218 \\
(0.299)\end{array}$ & $\begin{array}{c}1.770 \\
(0.272)\end{array}$ & - & - & $\begin{array}{c}-0.270 \\
(0.243)\end{array}$ & $\begin{array}{c}1.732 \\
(0.219)\end{array}$ & - & - \\
\hline Brand 6 & $\begin{array}{c}1.954 \\
(0.304)\end{array}$ & $\begin{array}{c}4.817 \\
(0.296)\end{array}$ & - & - & $\begin{array}{c}1.862 \\
(0.095)\end{array}$ & $\begin{array}{c}4.467 \\
(0.159)\end{array}$ & $\begin{array}{c}1.473 \\
(0.254)\end{array}$ & $\begin{array}{c}5.055 \\
(0.136)\end{array}$ \\
\hline Brand 7 & $\begin{array}{c}1.580 \\
(0.461)\end{array}$ & $\begin{array}{c}1.804 \\
(0.430)\end{array}$ & - & - & $\begin{array}{c}1.425 \\
(0.251)\end{array}$ & $\begin{array}{c}1.841 \\
(0.560)\end{array}$ & - & - \\
\hline Brand 8 & $0^{*}$ & $0^{*}$ & - & - & $0^{*}$ & $0^{*}$ & - & - \\
\hline Brand 9 & $\begin{array}{c}0.208 \\
(0.393)\end{array}$ & $\begin{array}{c}6.906 \\
(0.242)\end{array}$ & - & - & $\begin{array}{c}-0.903 \\
(0.259)\end{array}$ & $\begin{array}{c}6.457 \\
(0.218)\end{array}$ & $\begin{array}{c}0.549 \\
(0.315)\end{array}$ & $\begin{array}{c}7.247 \\
(0.465)\end{array}$ \\
\hline Brand 1 & - & - & - & - & - & - & $\begin{array}{c}1.558 \\
(0.118)\end{array}$ & $\begin{array}{c}6.911 \\
(0.179)\end{array}$ \\
\hline
\end{tabular}

* parameter fixed to ensure identification 
Table A.2

Parameter Estimates - Response (standard errors in parentheses)

\begin{tabular}{|c|c|c|c|}
\hline \multicolumn{2}{|l|}{ Model } & $\begin{array}{c}\text { Static } \\
\text { Model }\end{array}$ & Model 7 \\
\hline \multicolumn{4}{|c|}{ Segment size } \\
\hline & Seg. 1 & 0.105 & 0.107 \\
\hline & Seg. 2 & 0.251 & 0.261 \\
\hline & Seg. 3 & 0.192 & 0.222 \\
\hline & Seg. 4 & 0.231 & 0.236 \\
\hline & Seg. 5 & 0.222 & 0.174 \\
\hline \multirow[t]{4}{*}{ Seg. 1} & PRICE ${ }^{*}$ & $\begin{array}{c}1.528 \\
(0.175)\end{array}$ & $\begin{array}{c}3.072 \\
(0.115)\end{array}$ \\
\hline & PCUT & $\begin{array}{c}3.044 \\
(0.117)\end{array}$ & $\begin{array}{c}2.127 \\
(0.177)\end{array}$ \\
\hline & FEAT & $\begin{array}{c}0.165 \\
(0.408)\end{array}$ & $\begin{array}{c}-0.040 \\
(0.427)\end{array}$ \\
\hline & DISP & $\begin{array}{c}-0.741 \\
(0.388)\end{array}$ & $\begin{array}{c}-0.081 \\
(1.153)\end{array}$ \\
\hline \multirow[t]{4}{*}{ Seg. 2} & PRICE & $\begin{array}{c}-6.114 \\
(0.121)\end{array}$ & $\begin{array}{c}-6.522 \\
(0.443)\end{array}$ \\
\hline & PCUT & $\begin{array}{c}5.662 \\
(0.225)\end{array}$ & $\begin{array}{c}6.437 \\
(0.113)\end{array}$ \\
\hline & FEAT & $\begin{array}{c}0.391 \\
(0.368)\end{array}$ & $\begin{array}{c}0.319 \\
(0.302)\end{array}$ \\
\hline & DISP & $\begin{array}{c}0.204 \\
(0.428) \\
\end{array}$ & $\begin{array}{c}0.014 \\
(0.438)\end{array}$ \\
\hline \multirow[t]{4}{*}{ Seg. 3} & PRICE & $\begin{array}{l}-1.301 \\
(0.135)\end{array}$ & $\begin{array}{c}-1.052 \\
(0.152)\end{array}$ \\
\hline & PCUT & $\begin{array}{c}3.479 \\
(0.098)\end{array}$ & $\begin{array}{c}3.051 \\
(0.232)\end{array}$ \\
\hline & FEAT & $\begin{array}{l}-0.239 \\
(0.293)\end{array}$ & $\begin{array}{c}-0.157 \\
(0.422)\end{array}$ \\
\hline & DISP & $\begin{array}{c}-0.180 \\
(0.213) \\
\end{array}$ & $\begin{array}{c}-0.082 \\
(0.355)\end{array}$ \\
\hline \multirow[t]{4}{*}{ Seg. 4} & PRICE ${ }^{*}$ & $\begin{array}{c}9.243 \\
(0.035)\end{array}$ & $\begin{array}{c}10.707 \\
(0.264)\end{array}$ \\
\hline & PCUT & $\begin{array}{c}3.202 \\
(0.539)\end{array}$ & $\begin{array}{c}3.665 \\
(0.689)\end{array}$ \\
\hline & FEAT & $\begin{array}{c}0.647 \\
(0.284)\end{array}$ & $\begin{array}{c}0.659 \\
(0.166)\end{array}$ \\
\hline & DISP & $\begin{array}{c}1.021 \\
(0.603) \\
\end{array}$ & $\begin{array}{c}1.150 \\
(0.386) \\
\end{array}$ \\
\hline \multirow[t]{4}{*}{ Seg. 5} & PRICE ${ }^{*}$ & $\begin{array}{c}4.301 \\
(0.039)\end{array}$ & $\begin{array}{c}6.116 \\
(0.380)\end{array}$ \\
\hline & PCUT & $\begin{array}{c}1.813 \\
(0.148)\end{array}$ & $\begin{array}{c}2.289 \\
(0.172)\end{array}$ \\
\hline & FEAT & $\begin{array}{c}0.270 \\
(0.388)\end{array}$ & $\begin{array}{c}-0.006 \\
(0.347)\end{array}$ \\
\hline & DISP & $\begin{array}{c}3.865 \\
(0.693)\end{array}$ & $\begin{array}{c}2.690 \\
(0.204)\end{array}$ \\
\hline
\end{tabular}

* Positive price coefficients can be explained with the segmentation of the market in premium and non-premium brands. Some consumers (segments 1, 4, 5) regard the price level as an indicator for higher quality. Promotional price cut coefficients are all significant and have the expected positive signs. 


\section{SFB 649 Discussion Paper Series 2008}

For a complete list of Discussion Papers published by the SFB 649, please visit http://sfb649.wiwi.hu-berlin.de.

001 "Testing Monotonicity of Pricing Kernels" by Yuri Golubev, Wolfgang Härdle and Roman Timonfeev, January 2008.

002 "Adaptive pointwise estimation in time-inhomogeneous time-series models" by Pavel Cizek, Wolfgang Härdle and Vladimir Spokoiny, January 2008.

003 "The Bayesian Additive Classification Tree Applied to Credit Risk Modelling" by Junni L. Zhang and Wolfgang Härdle, January 2008.

004 "Independent Component Analysis Via Copula Techniques" by Ray-Bing Chen, Meihui Guo, Wolfgang Härdle and Shih-Feng Huang, January 2008.

005 "The Default Risk of Firms Examined with Smooth Support Vector Machines" by Wolfgang Härdle, Yuh-Jye Lee, Dorothea Schäfer and Yi-Ren Yeh, January 2008.

006 "Value-at-Risk and Expected Shortfall when there is long range dependence" by Wolfgang Härdle and Julius Mungo, Januray 2008.

007 "A Consistent Nonparametric Test for Causality in Quantile" by Kiho Jeong and Wolfgang Härdle, January 2008.

008 "Do Legal Standards Affect Ethical Concerns of Consumers?" by Dirk Engelmann and Dorothea Kübler, January 2008.

009 "Recursive Portfolio Selection with Decision Trees" by Anton Andriyashin, Wolfgang Härdle and Roman Timofeev, January 2008.

010 "Do Public Banks have a Competitive Advantage?" by Astrid Matthey, January 2008.

011 "Don't aim too high: the potential costs of high aspirations" by Astrid Matthey and Nadja Dwenger, January 2008.

012 "Visualizing exploratory factor analysis models" by Sigbert Klinke and Cornelia Wagner, January 2008.

013 "House Prices and Replacement Cost: A Micro-Level Analysis" by Rainer Schulz and Axel Werwatz, January 2008.

014 "Support Vector Regression Based GARCH Model with Application to Forecasting Volatility of Financial Returns" by Shiyi Chen, Kiho Jeong and Wolfgang Härdle, January 2008.

015 "Structural Constant Conditional Correlation" by Enzo Weber, January 2008.

016 "Estimating Investment Equations in Imperfect Capital Markets" by Silke Hüttel, Oliver Mußhoff, Martin Odening and Nataliya Zinych, January 2008.

017 "Adaptive Forecasting of the EURIBOR Swap Term Structure" by Oliver Blaskowitz and Helmut Herwatz, January 2008.

018 "Solving, Estimating and Selecting Nonlinear Dynamic Models without the Curse of Dimensionality" by Viktor Winschel and Markus Krätzig, February 2008.

019 "The Accuracy of Long-term Real Estate Valuations" by Rainer Schulz, Markus Staiber, Martin Wersing and Axel Werwatz, February 2008.

020 "The Impact of International Outsourcing on Labour Market Dynamics in Germany" by Ronald Bachmann and Sebastian Braun, February 2008.

021 "Preferences for Collective versus Individualised Wage Setting" by Tito Boeri and Michael C. Burda, February 2008.

\section{SFB 649, Spandauer Straße 1, D-10178 Berlin http:/ / sfb649.wiwi.hu-berlin.de}

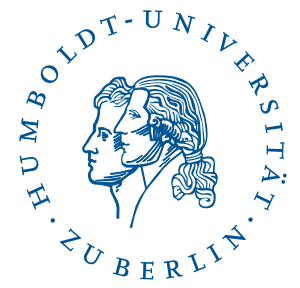


022 "Lumpy Labor Adjustment as a Propagation Mechanism of Business Cycles" by Fang Yao, February 2008.

023 "Family Management, Family Ownership and Downsizing: Evidence from S\&P 500 Firms" by Jörn Hendrich Block, February 2008.

024 "Skill Specific Unemployment with Imperfect Substitution of Skills" by Runli Xie, March 2008.

025 "Price Adjustment to News with Uncertain Precision" by Nikolaus Hautsch, Dieter Hess and Christoph Müller, March 2008.

026 "Information and Beliefs in a Repeated Normal-form Game" by Dietmar Fehr, Dorothea Kübler and David Danz, March 2008.

027 "The Stochastic Fluctuation of the Quantile Regression Curve" by Wolfgang Härdle and Song Song, March 2008.

028 "Are stewardship and valuation usefulness compatible or alternative objectives of financial accounting?" by Joachim Gassen, March 2008.

029 "Genetic Codes of Mergers, Post Merger Technology Evolution and Why Mergers Fail" by Alexander Cuntz, April 2008.

030 "Using R, LaTeX and Wiki for an Arabic e-learning platform" by Taleb Ahmad, Wolfgang Härdle, Sigbert Klinke and Shafeeqah Al Awadhi, April 2008.

031 "Beyond the business cycle - factors driving aggregate mortality rates" by Katja Hanewald, April 2008.

032 "Against All Odds? National Sentiment and Wagering on European Football" by Sebastian Braun and Michael Kvasnicka, April 2008.

033 "Are CEOs in Family Firms Paid Like Bureaucrats? Evidence from Bayesian and Frequentist Analyses" by Jörn Hendrich Block, April 2008.

034 "JBendge: An Object-Oriented System for Solving, Estimating and Selecting Nonlinear Dynamic Models" by Viktor Winschel and Markus Krätzig, April 2008.

035 "Stock Picking via Nonsymmetrically Pruned Binary Decision Trees" by Anton Andriyashin, May 2008.

036 "Expected Inflation, Expected Stock Returns, and Money Illusion: What can we learn from Survey Expectations?" by Maik Schmeling and Andreas Schrimpf, May 2008.

037 "The Impact of Individual Investment Behavior for Retirement Welfare: Evidence from the United States and Germany" by Thomas Post, Helmut Gründl, Joan T. Schmit and Anja Zimmer, May 2008.

038 "Dynamic Semiparametric Factor Models in Risk Neutral Density Estimation" by Enzo Giacomini, Wolfgang Härdle and Volker Krätschmer, May 2008.

039 "Can Education Save Europe From High Unemployment?" by Nicole Walter and Runli Xie, June 2008.

040 "Solow Residuals without Capital Stocks" by Michael C. Burda and Battista Severgnini, August 2008.

041 "Unionization, Stochastic Dominance, and Compression of the Wage Distribution: Evidence from Germany" by Michael C. Burda, Bernd Fitzenberger, Alexander Lembcke and Thorsten Vogel, March 2008

042 "Gruppenvergleiche bei hypothetischen Konstrukten - Die Prüfung der Übereinstimmung von Messmodellen mit der Strukturgleichungsmethodik" by Dirk Temme and Lutz Hildebrandt, June 2008.

043 "Modeling Dependencies in Finance using Copulae" by Wolfgang Härdle, Ostap Okhrin and Yarema Okhrin, June 2008.

044 "Numerics of Implied Binomial Trees" by Wolfgang Härdle and Alena Mysickova, June 2008.

\section{SFB 649, Spandauer Straße 1, D-10178 Berlin http:/ / sfb649.wiwi.hu-berlin.de}

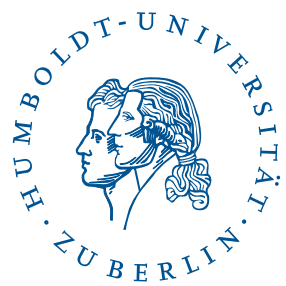


045 "Measuring and Modeling Risk Using High-Frequency Data" by Wolfgang Härdle, Nikolaus Hautsch and Uta Pigorsch, June 2008.

046 "Links between sustainability-related innovation and sustainability management" by Marcus Wagner, June 2008.

047 "Modelling High-Frequency Volatility and Liquidity Using Multiplicative Error Models" by Nikolaus Hautsch and Vahidin Jeleskovic, July 2008.

048 "Macro Wine in Financial Skins: The Oil-FX Interdependence" by Enzo Weber, July 2008.

049 "Simultaneous Stochastic Volatility Transmission Across American Equity Markets" by Enzo Weber, July 2008.

050 "A semiparametric factor model for electricity forward curve dynamics" by Szymon Borak and Rafał Weron, July 2008.

051 "Recurrent Support Vector Regreson for a Nonlinear ARMA Model with Applications to Forecasting Financial Returns" by Shiyi Chen, Kiho Jeong and Wolfgang K. Härdle, July 2008.

052 "Bayesian Demographic Modeling and Forecasting: An Application to U.S. Mortality" by Wolfgang Reichmuth and Samad Sarferaz, July 2008.

053 "Yield Curve Factors, Term Structure Volatility, and Bond Risk Premia" by Nikolaus Hautsch and Yangguoyi Ou, July 2008.

054 "The Natural Rate Hypothesis and Real Determinacy" by Alexander MeyerGohde, July 2008.

055 "Technology sourcing by large incumbents through acquisition of small firms" by Marcus Wagner, July 2008.

056 "Lumpy Labor Adjustment as a Propagation Mechanism of Business Cycle" by Fang Yao, August 2008.

057 "Measuring changes in preferences and perception due to the entry of a new brand with choice data" by Lutz Hildebrandt and Lea Kalweit, August 2008. 